\title{
The role of long-range transport and domestic emissions in determining atmospheric secondary inorganic particle concentrations across the UK
}

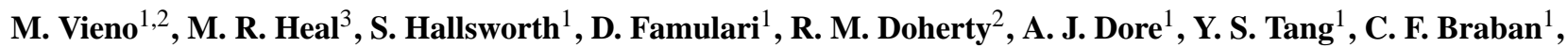 \\ D. Leaver ${ }^{1}$, M. A. Sutton ${ }^{1}$, and S. Reis ${ }^{1,4}$ \\ ${ }^{1}$ Natural Environment Research Council, Centre for Ecology \& Hydrology, Edinburgh Research Station, \\ Bush Estate, Penicuik, UK \\ ${ }^{2}$ School of GeoSciences, The University of Edinburgh, Edinburgh, UK \\ ${ }^{3}$ School of Chemistry, The University of Edinburgh, Edinburgh, UK \\ ${ }^{4}$ University of Exeter Medical School, Knowledge Spa, Truro, UK \\ Correspondence to: M. Vieno (vieno.massimo@gmail.com)
}

Received: 21 October 2013 - Published in Atmos. Chem. Phys. Discuss.: 23 December 2013

Revised: 8 July 2014 - Accepted: 11 July 2014 - Published: 21 August 2014

\begin{abstract}
Surface concentrations of secondary inorganic particle components over the UK have been analysed for 2001-2010 using the EMEP4UK regional atmospheric chemistry transport model and evaluated against measurements. Gas/particle partitioning in the EMEP4UK model simulations used a bulk approach, which may lead to uncertainties in simulated secondary inorganic aerosol. However, model simulations were able to accurately represent both the long-term decadal surface concentrations of particle sulfate and nitrate and an episode in early 2003 of substantially elevated nitrate measured across the UK by the AGANet network. The latter was identified as consisting of three separate episodes, each of less than 1 month duration, in February, March and April. The primary cause of the elevated nitrate levels across the UK was meteorological: a persistent high-pressure system, whose varying location impacted the relative importance of transboundary versus domestic emissions. Whilst long-range transport dominated the elevated nitrate in February, in contrast it was domestic emissions that mainly contributed to the March episode, and for the April episode both domestic emissions and long-range transport contributed. A prolonged episode such as the one in early 2003 can have substantial impact on annual average concentrations. The episode led to annual concentration differences at the regional scale of similar magnitude to those driven by long-term changes in precursor emissions over the full decade investigated here. The results demonstrate that a sub-
\end{abstract}

stantial part of the UK, particularly the south and southeast, may be close to or exceeding annual mean limit values because of import of inorganic aerosol components from continental Europe under specific conditions. The results reinforce the importance of employing multiple year simulations in the assessment of emissions reduction scenarios on particulate matter concentrations and the need for international agreements to address the transboundary component of air pollution.

\section{Introduction}

Atmospheric particulate matter (PM) concentrations are governed by the transport, transformation and deposition of many chemical species. PM has a range of impacts including on climate through radiative forcing and on human health. Considering the health impacts alone, exposure to $\mathrm{PM}_{2.5}$ (the size fraction of particles with an aerodynamic diameter $\leq 2.5 \mu \mathrm{m}$ ) has been estimated to contribute to an average loss of life expectancy of around 6-7 months for residents of the UK, with an associated economic cost of some $£ 16$ billion per annum (IGCB, 2007). EU legislation sets standards for ambient concentrations of PM, and now includes an obligation on individual member states to reduce 
population-weighted exposure to $\mathrm{PM}_{2.5}$ by a specified percentage between 2010 and 2020 (Heal et al., 2012).

The complexity of ambient PM composition and formation, combined with the influence of meteorology on chemistry, dispersion and deposition, considerably complicates pinpointing the contributions of different chemical pollutant emission sources to ambient PM at specific locations (AQEG, 2012). Consequently, it is a complicated process to formulate cost-effective policy action to reduce harm caused by PM. The inorganic chemical components of PM - ammonium $\left(\mathrm{NH}_{4}^{+}\right)$, sulfate $\left(\mathrm{SO}_{4}^{2-}\right)$ and nitrate $\left(\mathrm{NO}_{3}^{-}\right)$- constitute a major fraction of $\mathrm{PM}_{2.5}$ (Putaud et al., 2010). The anthropogenic emissions of the gaseous precursors of inorganic $\mathrm{PM}$ - ammonia $\left(\mathrm{NH}_{3}\right)$, sulfur dioxide $\left(\mathrm{SO}_{2}\right)$ and nitrogen oxides $\left(\mathrm{NO}_{\mathrm{X}}\right)$ - are also subject to various legislation that seeks to limit and reduce either a country's total emissions or the emissions from individual sources or source sectors (Heal et al., 2012; Reis et al., 2012). For $\mathrm{SO}_{2}$ and $\mathrm{NO}_{\mathrm{x}}$ in particular, emissions reductions have been very effective over the past few decades and this is reflected in reductions in ambient concentrations of the gases (RoTAP, 2012). Despite this, $\mathrm{PM}_{10}$ concentrations across much of western Europe have not fallen significantly since the year 2000 (Harrison et al., 2008).

The longer lifetime of secondary PM components compared with their gaseous precursors means that transboundary transport from Europe and meteorology are important drivers. Previous studies suggest that transatlantic transport of these secondary inorganic aerosol (SIA) species has a small effect on EU surface SIA concentrations and deposition (Sanderson et al., 2008; Simpson et al., 2012), hence "transboundary" hereafter refers to Europe. This is of particular relevance for the design of air quality policies seeking to reduce PM concentrations, especially as some limit values may be sensitive to a small number of high-concentration episodes rather than long-term average concentrations. This is particularly important for the nitrate component which has been shown to be the dominant component on days when $\mathrm{PM}_{10}$ exceeds $50 \mu \mathrm{g} \mathrm{m}^{-3}$ (Yin and Harrison, 2008).

There remains a gap in understanding the extent to which domestic emissions and transboundary import of secondary inorganic PM contribute inter-annually and to episodes of elevated concentrations in the UK (RoTAP). This was the motivation for this work. Ambient concentrations of the inorganic components have been measured since the 1990s on a monthly average basis, as part of the UK Acid Gas and Aerosol Network (AGANet http://uk-air.defra.gov.uk/ networks/network-info?view=aganet, see Tang et al. (2009) for description of the approach), providing a data set against which to compare model output.

In Sect. 2 the modelling approach using the EMEP4UK Eulerian atmospheric chemistry transport model (ACTM) (Vieno et al., 2009, 2010) simulations and AGANet measurements are fully described. In Sect. 3, first the model performance is evaluated against these AGANet measurements and

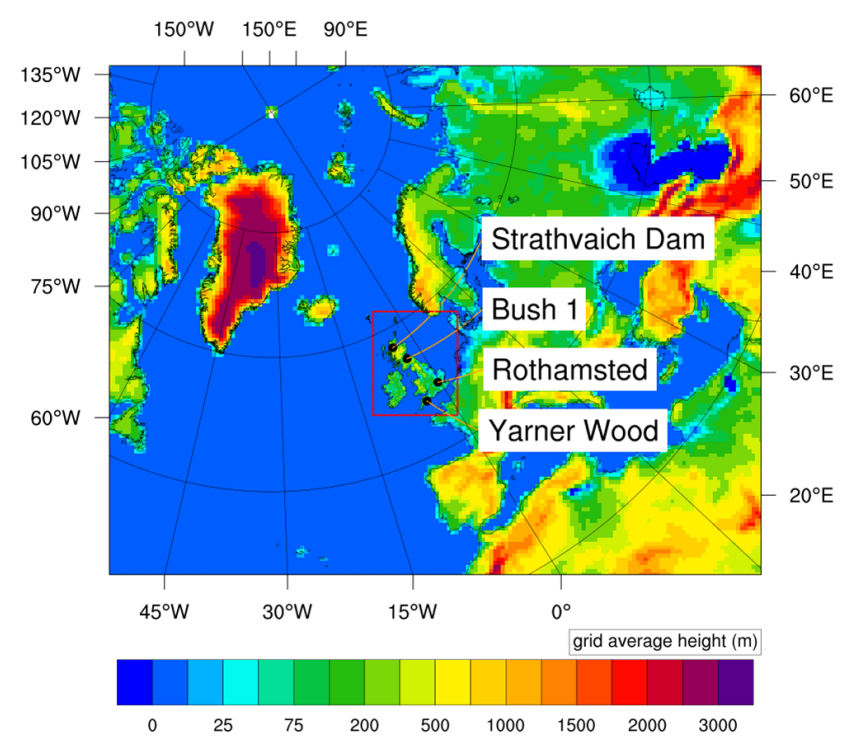

Figure 1. The EMEP4UK Greater European domain, modelled at $50 \mathrm{~km} \times 50 \mathrm{~km}$ horizontal resolution and, outlined in red, the nested British Isles domain, modelled at $5 \mathrm{~km} \times 5 \mathrm{~km}$ horizontal resolution. The colour scale indicates grid-average altitude. The four UK AGANet measurement sites used in this study are also shown.

then the results of sensitivity simulations to assess the contributions of trans-boundary and domestic emissions to secondary inorganic particle concentrations in the UK and their inter-annual variability are assessed. Section 4 discusses this novel decadal inter-comparison and attribution results and conclusions are presented in Sect. 5.

\section{Methods}

\subsection{Model description and setup}

The EMEP4UK model used for this work is a nested regional ACTM based on version v3.7 of the main EMEP MSC-W model (Simpson et al., 2012). A detailed description of the EMEP4UK model framework and setup are given in Vieno et al. (2010) and only brief relevant details are presented here.

The EMEP4UK model is driven by the Weather Research Forecast (WRF) model version 3.1.1 (http://www.wrf-model. org). The model horizontal resolution scales down from $50 \mathrm{~km} \times 50 \mathrm{~km}$ in the main EMEP "Greater European" domain to $5 \mathrm{~km} \times 5 \mathrm{~km}$ for the domain covering the British Isles (Fig. 1). The boundary conditions for the inner domain are derived from the results of the European domain in a one-way nested setup. The EmChem09 chemical scheme was chosen for the present study, as it has been extensively validated at the European scale (Simpson et al., 2012, www.emep.int). The EMEP model is based on Berge and Jakobsen (1998), but extended with photo-oxidant chemistry (Andersson-Skold and Simpson, 1999; Simpson et al., 
1995). The EmChem09 mechanism used for this work has 72 species and 137 reactions. Full details of the chemical scheme are given by Simpson et al. (2012). Gas/aerosol partitioning used the EQSAM formulation (Metzger et al., $2002 a, b)$. The calculated nitrate is then split into coarse and fine mode using a parameterised approach dependent on relative humidity, as described by Simpson et al. (2012). In this version of the EMEP model, nitrate is the only secondary inorganic component present in $\mathrm{PM}_{\text {coarse }}$ (the difference between $\mathrm{PM}_{10}$ and $\mathrm{PM}_{2.5}$ ). This split between $\mathrm{PM}_{2.5}$ and $\mathrm{PM}_{2.5-10}$ for nitrate is rather uncertain as discussed in Aas et al. (2012); a more explicit aerosol scheme is under development. The EQSAM scheme used here is equivalent to the EQSAM2 scheme used in the global model TM5 (Karl et al., 2009; Huijnen et al., 2010).

Anthropogenic emissions of $\mathrm{NO}_{\mathrm{x}}, \mathrm{NH}_{3}, \mathrm{SO}_{2}$, primary $\mathrm{PM}_{2.5}$, primary $\mathrm{PM}_{\text {coarse }}, \mathrm{CO}$ and non-methane volatile organic compounds are included. $\mathrm{PM}_{10}$ is the size fraction of particles with an aerodynamic diameter $\leq 10 \mu \mathrm{m}$. For the UK, emissions values are taken from the National Atmospheric Emission Inventory (NAEI, http://naei.defra.gov.uk) at $1 \mathrm{~km}^{2}$ resolution and aggregated to $5 \mathrm{~km} \times 5 \mathrm{~km}$ resolution. The underpinning methods by which these emission inventories have been established are reported by Hellsten et al. (2008) and Dore et al. (2008). For the rest of the outer domain, the model uses the EMEP $50 \mathrm{~km} \times 50 \mathrm{~km}$ resolution emission estimates provided by the Centre for Emission Inventories and Projections (CEIP, http://www.ceip.at/). Emissions estimates for international shipping (ENTEC, 2010) are aggregated to $5 \mathrm{~km} \times 5 \mathrm{~km}$ for those emissions within the inner domain. The EMEP(4UK) model uses a yearly boundary condition for SIA at the edge of the European domain adjusted for each year as described in Simpson et al. (2012).

\subsection{Model experiments}

Hourly surface concentrations of several pollutants, including $\mathrm{NO}_{2}, \mathrm{SO}_{2}$ and $\mathrm{NH}_{3}$, and particle $\mathrm{NO}_{3}^{-}, \mathrm{SO}_{4}^{2-}$ and $\mathrm{NH}_{4}^{+}$, were simulated for the decade 2001-2010. To quantify the influence of long-range (i.e. non-UK, or "transboundary") and short-range (UK, "domestic") emissions on the UK surface concentrations of these components, a perturbation experiment was carried out by setting UK land emissions to zero for the year. This provides an approximate model estimate of the contribution of non-UK emissions to gaseous and PM concentrations in the UK.

\subsection{Measurement data}

Model surface concentrations were compared with observational data from the UK Acid Gases and Aerosols Network (AGANet), which is one of the four component UK Eutrophying and Acidifying Pollutants monitoring networks (Conolly et al., 2011; Tang et al., 2013). The AGANet monitoring sites were established in 1999 for the long-term simul- taneous measurement of the concentrations of $\mathrm{SO}_{2}, \mathrm{HNO}_{3}$ and $\mathrm{NH}_{3}$ gases and particle $\mathrm{NO}_{3}^{-}, \mathrm{SO}_{4}^{2-}$ and $\mathrm{NH}_{4}^{+}$, in relation to changes in European emissions of $\mathrm{SO}_{2}, \mathrm{NO}_{\mathrm{x}}$ and $\mathrm{NH}_{3}$. Measurements are made using DELTA system (DEnuder for Long-Term Atmospheric sampling) and have monthly averaged time resolution (Sutton et al., 2001). The size cut-off of the DELTA sampler has been estimated to be $\sim 4.5 \mu \mathrm{m}$ (Tang et al., 2009), therefore the measured concentrations are between the $\mathrm{PM}_{2.5}$ and $\mathrm{PM}_{10}$ size fractions.

The EMEP4UK model assigns all $\mathrm{SO}_{4}^{2-}$ and $\mathrm{NH}_{4}^{+}$components to $\mathrm{PM}_{2.5}$. Modelled $\mathrm{NO}_{3}^{-}$is assigned to both $\mathrm{PM}_{2.5}$ and $\mathrm{PM}_{\text {coarse }}$ which leads to potential negative bias in modelled versus measured concentrations for $\mathrm{NO}_{3}^{-}$. Four sites representing different areas of the UK (marked on Fig. 1) have been selected for the comparisons presented here: Strathvaich Dam (northwest Scotland); Bush (central Scotland); Rothamsted (southeast England); and Yarner Wood (southwest England).

\section{Results}

The time series of the modelled and observed monthly mean surface concentrations of particle $\mathrm{NO}_{3}^{-}$and $\mathrm{SO}_{4}^{2-}$ at the four selected AGANet sites are shown in Figs. 2 and 3, respectively. The observations span the period 2001-2010, whereas the model values span the period 2001-2010. A peak in 2003 in $\mathrm{NO}_{3}^{-}$concentrations can be seen in both observations and the EMEP4UK simulations. Figures 2 and 3 show generally good agreement between the two data sets for three of the four sites included here, as illustrated quantitatively by the correlation and linear regression statistics for these particlephase components and for the gas-phase species $\mathrm{HNO}_{3}$ and $\mathrm{SO}_{2}$ (Table 1). The model-measurement comparison at the Strathvaich Dam site is adversely impacted by two extreme measurement values in 2006 and 2007 not present in the simulations. No anomaly is present in the meteorology at this location for these two months. From an analysis of the mass balance of the aerosol components, the two anomalous data points appear to be outliers which may be attributed to sampling or analytical contamination in determination of $\mathrm{NO}_{3}^{-}$ and $\mathrm{SO}_{4}^{2-}$. The anomaly could be potentially due to local influence or an unusually high positive artefact on the $\mathrm{HNO}_{3}$. Recent investigations indicate that the $\mathrm{AGANet}^{\mathrm{HNO}} \mathrm{O}_{3}$ observation using the DELTA methodology includes a positive bias from other $\mathrm{NO}_{\mathrm{y}}$ chemical species, which could include HONO (heterogeneously oxidised), $\mathrm{N}_{2} \mathrm{O}_{5}$ and PANs (Peroxyacetyl nitrate). However, there is nothing to indicate that Strathvaich Dam should be affected more from this than other sites.

The spatial pattern across the British Isles and the interyear variability of modelled annual mean surface concentrations are shown in Fig. 4 for $\mathrm{NO}_{2}, \mathrm{SO}_{2}$ and $\mathrm{NH}_{3}$ and in Fig. 5 for particle $\mathrm{NO}_{3}^{-}, \mathrm{SO}_{4}^{2-}$ and $\mathrm{NH}_{4}^{+}$. In each case, the top left panel shows the spatial distribution for 2001 and 
Table 1. Mean concentrations, and correlation and regression statistics, for monthly averaged modelled and measured $\mathrm{NO}_{3}^{-}$and $\mathrm{SO}_{4}^{2-}$ in particulate matter, and $\mathrm{HNO}_{3}$ and $\mathrm{SO}_{2}$ gas for the period 2001-2010 at four sites of the AGANet network: Strathvaich Dam (northwest Scotland), Bush 1 (central Scotland), Rothamsted (southeast England), and Yarner Wood (southwest England). The comparison is based on a linear fit where measurement $=$ slope $\times$ model + intercept.

\begin{tabular}{|c|c|c|c|c|}
\hline & \multicolumn{4}{|c|}{ Particulate $\mathrm{NO}_{3}^{-}$} \\
\hline & Strathvaich Dam & Bush 1 & Rothamsted & Yarner Wood \\
\hline Measurement mean & $0.49 \mu \mathrm{g} \mathrm{m}^{-3}$ & $1.37 \mu \mathrm{g} \mathrm{m}^{-3}$ & $3.35 \mu \mathrm{g} \mathrm{m}^{-3}$ & $1.98 \mu \mathrm{g} \mathrm{m}^{-3}$ \\
\hline Model mean & $0.77 \mu \mathrm{g} \mathrm{m}^{-3}$ & $1.42 \mu \mathrm{g} \mathrm{m}^{-3}$ & $2.73 \mu \mathrm{g} \mathrm{m}^{-3}$ & $2.23 \mu \mathrm{g} \mathrm{m}^{-3}$ \\
\hline$r$ & 0.49 & 0.91 & 0.81 & 0.86 \\
\hline Slope & 0.59 & 0.96 & 0.68 & 0.95 \\
\hline \multirow[t]{3}{*}{ Intercept } & $0.48 \mu \mathrm{g} \mathrm{m}^{-3}$ & $0.10 \mu \mathrm{g} \mathrm{m}^{-3}$ & $0.44 \mu \mathrm{g} \mathrm{m}^{-3}$ & $0.34 \mu \mathrm{g} \mathrm{m}^{-3}$ \\
\hline & \multicolumn{4}{|c|}{ Particulate $\mathrm{SO}_{4}^{2-}$} \\
\hline & Strathvaich Dam & Bush 1 & Rothamsted & Yarner Wood \\
\hline Measurement mean & $0.57 \mu \mathrm{g} \mathrm{m}^{-3}$ & $0.94 \mu \mathrm{g} \mathrm{m}^{-3}$ & $1.75 \mu \mathrm{g} \mathrm{m}^{-3}$ & $1.20 \mu \mathrm{g} \mathrm{m}^{-3}$ \\
\hline Model mean & $0.61 \mu \mathrm{g} \mathrm{m}^{-3}$ & $0.95 \mu \mathrm{g} \mathrm{m}^{-3}$ & $1.48{\mu \mathrm{g} \mathrm{m}^{-3}}^{-3}$ & $1.28 \mu \mathrm{g} \mathrm{m}^{-3}$ \\
\hline$r$ & 0.72 & 0.79 & 0.65 & 0.69 \\
\hline Slope & 0.86 & 0.76 & 0.56 & 0.65 \\
\hline \multirow[t]{3}{*}{ Intercept } & $0.12 \mu \mathrm{g} \mathrm{m}^{-3}$ & $0.24 \mu \mathrm{g} \mathrm{m}^{-3}$ & $0.50 \mu \mathrm{g} \mathrm{m}^{-3}$ & $0.36 \mu \mathrm{g} \mathrm{m}^{-3}$ \\
\hline & \multicolumn{4}{|c|}{$\mathrm{HNO}_{3}$} \\
\hline & Strathvaich Dam & Bush 1 & Rothamsted & Yarner Wood \\
\hline Measurement mean & $0.23 \mu \mathrm{g} \mathrm{m}^{-3}$ & $0.57 \mu \mathrm{g} \mathrm{m}^{-3}$ & $1.89 \mu \mathrm{g} \mathrm{m}^{-3}$ & $0.73 \mu \mathrm{g} \mathrm{m}^{-3}$ \\
\hline Model mean & $0.16 \mu \mathrm{g} \mathrm{m}^{-3}$ & $0.36 \mu \mathrm{g} \mathrm{m}^{-3}$ & $0.96 \mu \mathrm{g} \mathrm{m}^{-3}$ & $0.56 \mu \mathrm{g} \mathrm{m}^{-3}$ \\
\hline$r$ & 0.77 & 0.45 & 0.35 & 0.59 \\
\hline Slope & 0.59 & 0.44 & 0.32 & 0.65 \\
\hline \multirow[t]{3}{*}{ Intercept } & $0.03 \mu \mathrm{g} \mathrm{m}^{-3}$ & $0.11 \mu \mathrm{g} \mathrm{m}^{-3}$ & $0.36 \mu \mathrm{g} \mathrm{m}^{-3}$ & $0.09 \mu \mathrm{g} \mathrm{m}^{-3}$ \\
\hline & \multicolumn{4}{|c|}{$\mathrm{SO}_{2}$} \\
\hline & Strathvaich Dam & Bush 1 & Rothamsted & Yarner Wood \\
\hline Measurement mean & $0.18 \mu \mathrm{g} \mathrm{m}^{-3}$ & $1.28 \mu \mathrm{g} \mathrm{m}^{-3}$ & $1.92 \mu \mathrm{g} \mathrm{m}^{-3}$ & $0.75 \mu \mathrm{g} \mathrm{m}^{-3}$ \\
\hline Model mean & $0.43 \mu \mathrm{g} \mathrm{m}^{-3}$ & $1.43 \mu \mathrm{g} \mathrm{m}^{-3}$ & $2.05 \mathrm{\mu g} \mathrm{m}^{-3}$ & $1.16 \mu \mathrm{g} \mathrm{m}^{-3}$ \\
\hline$r$ & 0.62 & 0.60 & 0.80 & 0.83 \\
\hline Slope & 1.5 & 0.57 & 0.71 & 1.09 \\
\hline Intercept & $0.16 \mu \mathrm{g} \mathrm{m}^{-3}$ & $0.71 \mu \mathrm{g} \mathrm{m}^{-3}$ & $0.68 \mu \mathrm{g} \mathrm{m}^{-3}$ & $0.35 \mu \mathrm{g} \mathrm{m}^{-3}$ \\
\hline
\end{tabular}

the other nine panels show the differences in annual mean concentrations for each of years 2002-2010 relative to 2001. The maps for 2001 show highest concentrations of $\mathrm{NO}_{2}$ and $\mathrm{SO}_{2}$ over central and southeast England, related to UK emission sources, and over the English Channel, mostly related to shipping emission sources. The highest concentrations of $\mathrm{NO}_{2}$ and $\mathrm{SO}_{2}$ over the UK are in 2003, with the lowest concentrations during 2008-2010. The extended periods of elevated $\mathrm{NO}_{3}^{-}$between February and April 2003 were sufficient to enhance the annual average $\mathrm{NO}_{3}^{-}$concentration across the whole of the UK in 2003 by between 0.2 and $0.3 \mu \mathrm{g} \mathrm{N} \mathrm{m}^{-3}$ compared with preceding and subsequent years (Fig. 5a), with a even larger enhancement in the annual mean for 2003 of $0.2-0.5 \mu \mathrm{g} \mathrm{N} \mathrm{m}^{-3}$ for $\mathrm{NH}_{4}^{+}$(Fig. 5c). In contrast, the somewhat less elevated $\mathrm{SO}_{4}^{2-}$ concentrations during this period led to a modest increase in annual average $\mathrm{SO}_{4}^{2-}$ for 2003 of $0.0-0.1 \mu \mathrm{g} \mathrm{S} \mathrm{m}^{-3}$ (Fig. 5b). The spatial distribution of $\mathrm{NH}_{3}$ shows a very different pattern to the other modelled components, with highest modelled concentrations in Brittany and northwest France and northwest England, reflecting the distribution of modelled $\mathrm{NH}_{3}$ emissions which mainly arise from agricultural sources.

The concentrations of the particle components $\mathrm{NO}_{3}^{-}$, $\mathrm{SO}_{4}^{2-}$ and $\mathrm{NH}_{4}^{+}$are spatially smoother across the UK than the gaseous precursors (Figs. 4 and 5). The modelled annual surface concentrations of $\mathrm{NO}_{2}$ and $\mathrm{SO}_{2}$ (Fig. 4a and b) show that the concentrations of these gaseous components decline during 2001-2010 by substantially more than the decline in $\mathrm{NO}_{3}^{-}$and $\mathrm{SO}_{4}^{2-}$. Over much of the UK (particularly England), declines in modelled $\mathrm{NO}_{2}$ and $\mathrm{SO}_{2}$ between 2001 


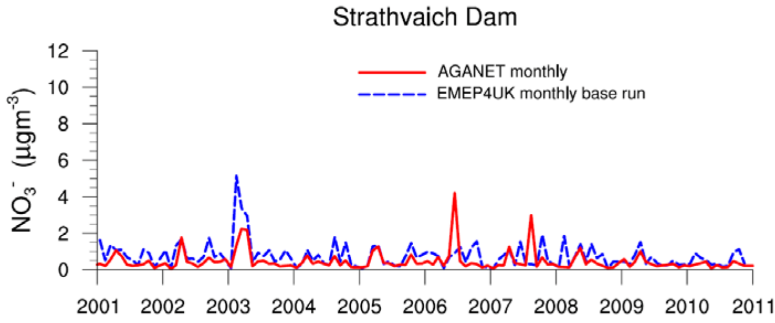

a)

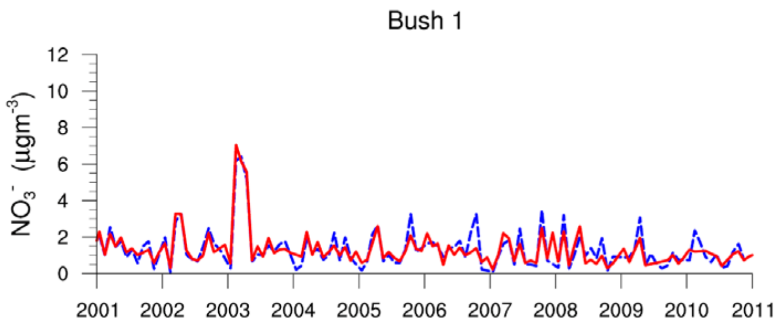

b)

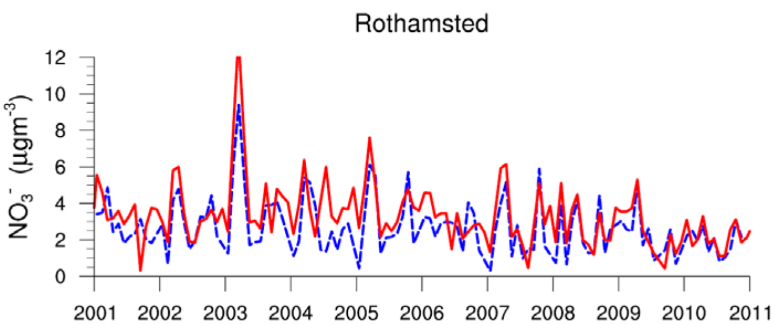

c)

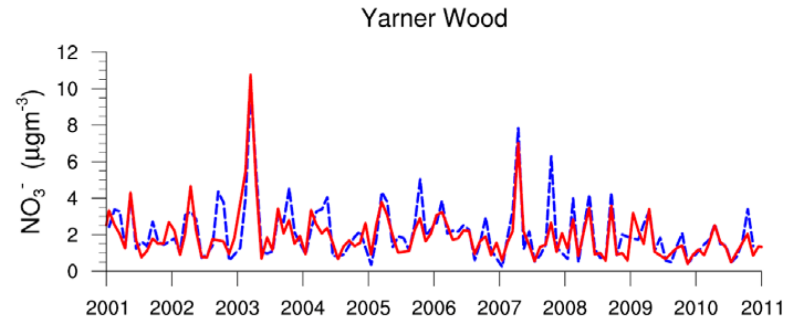

d)

Figure 2. Monthly average surface concentrations of particulate matter nitrate, observed (red) and modelled (blue), for 2001-2010 at four sites of the AGANet network: Strathvaich Dam (northwest Scotland), Bush (central Scotland), Rothamsted (southeast England), and Yarner Wood (southwest England).

and 2010 exceed $1 \mu \mathrm{g} \mathrm{N} / \mathrm{S} \mathrm{m}^{-3}$ in 2010 compared with the $0.1-0.2 \mu \mathrm{g} \mathrm{N} \mathrm{m}^{-3}$ decline in $\mathrm{NO}_{3}^{-}$, and the $0.1-0.3 \mu \mathrm{g} \mathrm{S} \mathrm{m}{ }^{-3}$ decline in $\mathrm{SO}_{4}^{2-}$ (up to $0.4 \mu \mathrm{g} \mathrm{S} \mathrm{m}{ }^{-3}$ decline in eastern England). On the other hand, the model shows concentrations of $\mathrm{NH}_{3}$ hardly changing over the decade - in fact increasing slightly, up to $\sim 0.2 \mu \mathrm{g} \mathrm{N} \mathrm{m}^{-3}$ over England, especially for 2009 and 2010 (Fig. 4c) - whereas, with the exception of 2003, the modelled concentration of $\mathrm{NH}_{4}^{+}$in $\mathrm{PM}$ decreases from 2001 to 2010 . Of note also is a decrease of $\mathrm{SO}_{2}$ annual surface concentration over the North Sea from 2007 onwards (Fig. 4b).

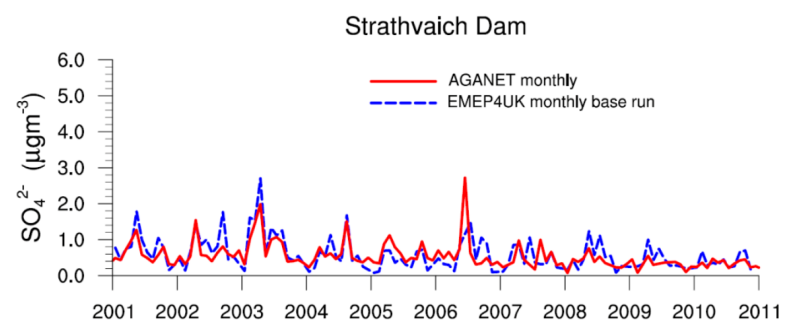

a)

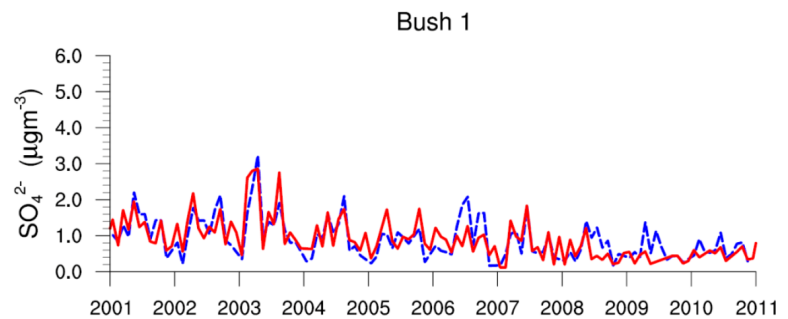

b)

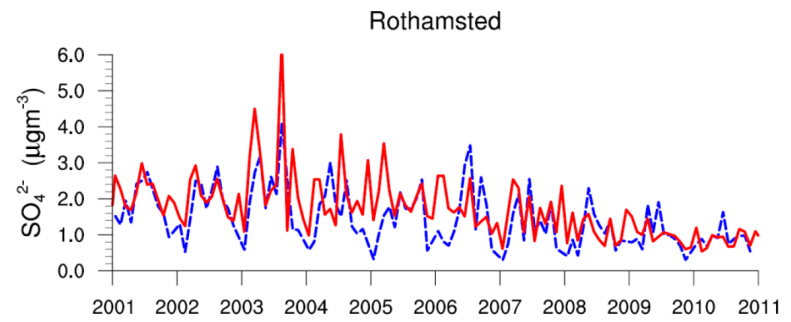

c)

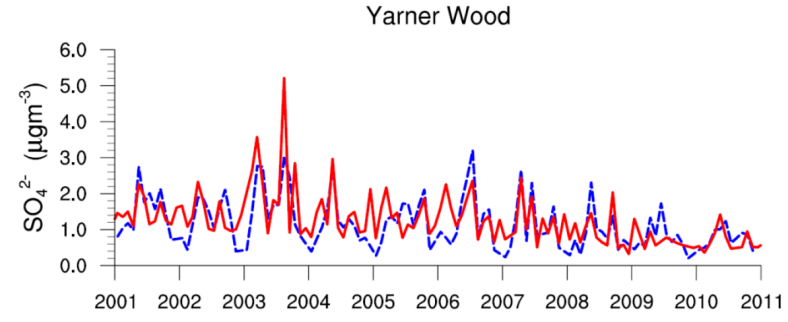

d)

Figure 3. Monthly average surface concentration of particulate matter sulfate, observed (red) and modelled (blue), for 2001-2010 at four sites of the AGANet network: Strathvaich Dam (northwest Scotland), Bush (central Scotland), Rothamsted (southeast England), and Yarner Wood (southwest England).

Figure 6a and $\mathrm{b}$ (upper panels) show the modelled monthly mean surface concentrations of $\mathrm{NO}_{2}$ and $\mathrm{SO}_{2}$, respectively, for the first 5 months of 2003, which covers the period of high secondary inorganic particle concentrations shown in (Figs. 2 and 3). To highlight the role of UK sources, the differences between the base simulations and the simulations with zero UK emissions are shown in the lower panels of Fig. 6a and $b$, with the data expressed as the percentage of the modelled concentrations that are directly attributable to UK domestic emissions (i.e. $100 \times($ Base Run - Experiment)/Base), again as monthly averages. While the lower maps clearly show the dominating contribution of UK domestic sources to $\mathrm{NO}_{2}$ and $\mathrm{SO}_{2}$ concentrations over mainland $\mathrm{UK}$, a smaller 
a)

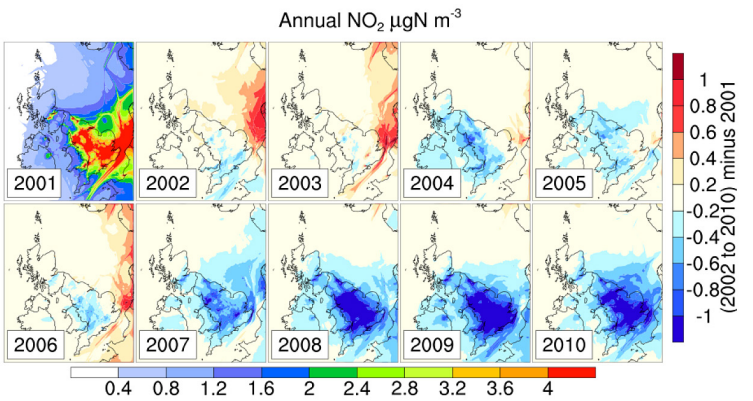

b)

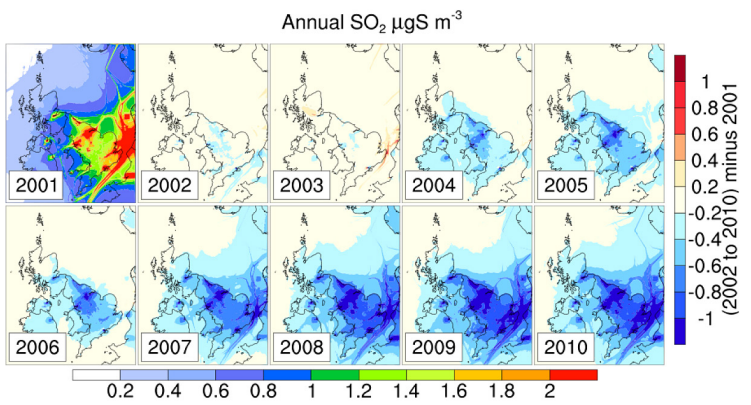

c)

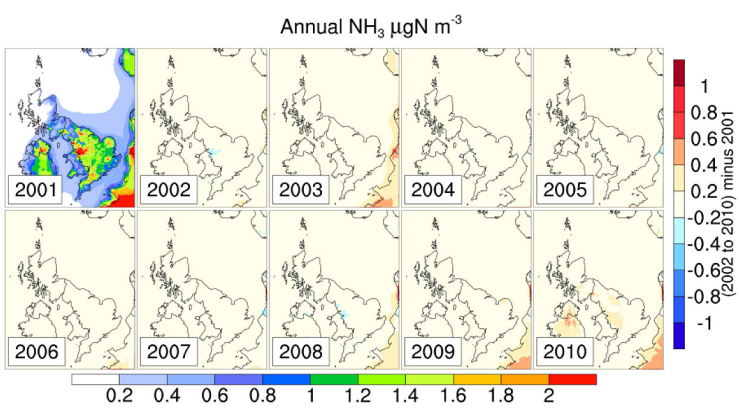

Figure 4. Modelled annual average surface concentrations of (a) $\mathrm{NO}_{2}$, (b) $\mathrm{SO}_{2}$ and (c) $\mathrm{NH}_{3}$. The top left panel of each figure shows the concentrations in 2001 (horizontal scales in $\mu \mathrm{g} \mathrm{N} \mathrm{m}^{-3}$ or $\mu \mathrm{g} \mathrm{S} \mathrm{m}^{-3}$, as relevant). The remaining panels illustrate the difference in surface concentrations in each of years 2002 to 2010 compared with 2001 (vertical scales in $\mu \mathrm{g} \mathrm{N} \mathrm{m}^{-3}$ or $\mu \mathrm{g} \mathrm{S} \mathrm{m}^{-3}$, as relevant).

contribution in the vicinity of major shipping channels reflects the fact that the scenario treated international shipping as part of the non-UK emissions.

Figure $7 \mathrm{a}$ and $\mathrm{b}$ show similar model results to Fig. 6 but for surface concentrations of particle $\mathrm{NO}_{3}^{-}$and $\mathrm{SO}_{4}^{2-}$, respectively. For these components, there is a smaller percentage contribution from UK sources than for $\mathrm{SO}_{2}$ and $\mathrm{NO}_{\mathrm{x}}$ concentrations.

The highest concentrations of $\mathrm{NO}_{2}$ and $\mathrm{SO}_{2}$ occurred during February and March (Fig. 6), with highest concentrations for $\mathrm{NO}_{3}^{-}$and $\mathrm{SO}_{4}^{2-}$ occurring during February, March and April (Fig. 7). Figure 7 shows that, for February, up to $40 \%$ of the monthly average $\mathrm{NO}_{3}^{-}$concentrations over the UK are attributable to UK emissions. In March and April, the UK contribution to $\mathrm{NO}_{3}^{-}$concentrations rises to up to $80 \%$. a)

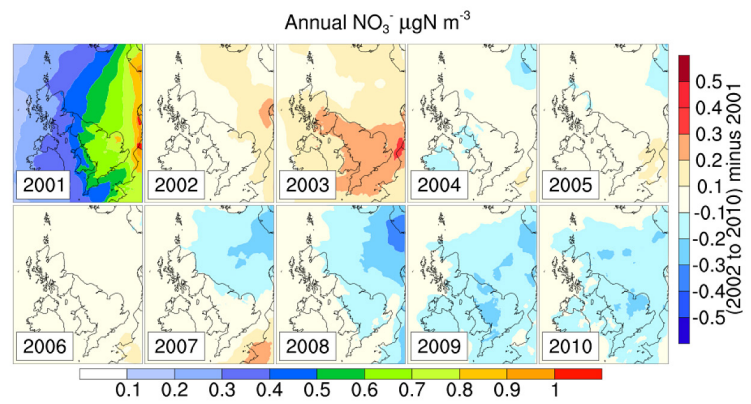

b)

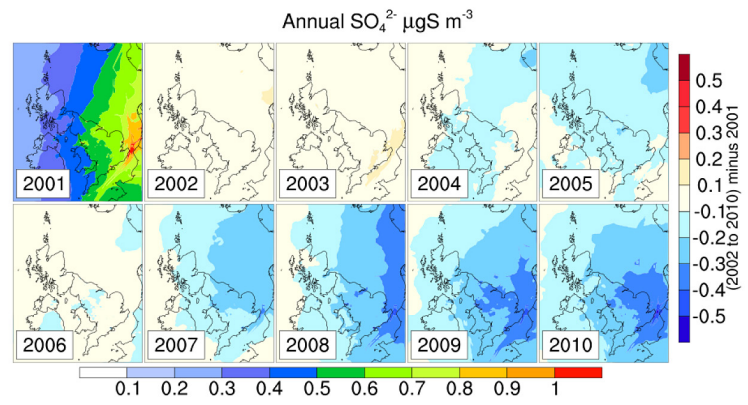

c)

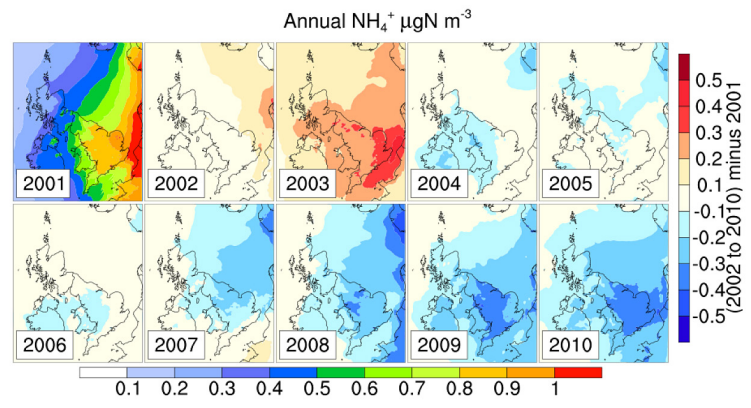

Figure 5. Modelled annual average surface concentrations of (a) $\mathrm{NO}_{3}^{-}$, (b) $\mathrm{SO}_{4}^{2-}$ and (c) $\mathrm{NH}_{4}^{+}$. The top left panel of each figure shows the concentrations in 2001 (horizontal scales in $\mu \mathrm{g} \mathrm{N} \mathrm{m}^{-3}$ or $\mu \mathrm{g} \mathrm{S} \mathrm{m}^{-3}$, as relevant). The remaining panels illustrate the difference in surface concentrations in each of years 2002 to 2010 compared with 2001 (vertical scales in $\mu \mathrm{g} \mathrm{N} \mathrm{m}^{-3}$ or $\mu \mathrm{g} \mathrm{S} \mathrm{m}^{-3}$, as relevant).

The spatial pattern of the UK contribution to these concentrations differs between the months, with February showing the smallest contribution of $\mathrm{UK}$ sources to $\mathrm{SO}_{2}, \mathrm{NO}_{2}, \mathrm{NO}_{3}^{-}$ and $\mathrm{SO}_{4}^{2-}$ concentrations. In contrast, the episodes in March and April 2003 have substantially larger contributions of UK emissions to $\mathrm{NO}_{3}^{-}$and $\mathrm{SO}_{4}^{2-}$ concentrations.

A detailed comparison for 2003 between the measured and modelled $\mathrm{NO}_{3}^{-}$concentrations at the Bush 1 site (Scotland) is shown in Fig. 8 with the modelled values presented as both monthly and daily means. There is a close agreement between observations (red line) and model (blue line) for these high-concentration episodes, with the monthly values broadly agreeing within $10 \%$. 

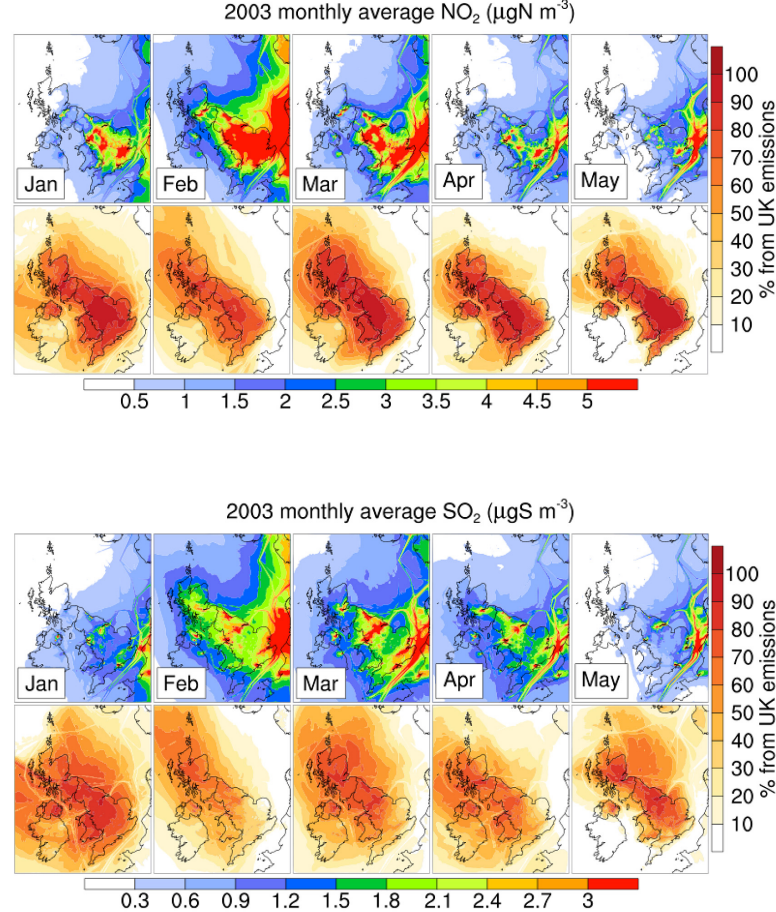

Figure 6. Modelled monthly average surface concentrations and UK contributions for (a) $\mathrm{NO}_{2}$ and (b) $\mathrm{SO}_{2}$ through January to May 2003. In each case the upper panel shows the mean concentrations ( $\mu \mathrm{g} \mathrm{N} \mathrm{m}^{-3}$ or $\mu \mathrm{g} \mathrm{S} \mathrm{m}^{-3}$ ), while the lower panel shows the percentage contribution from UK emissions (calculated as [100 $\times($ Base - no UK emi $) /$ Base] between the base simulation and the simulation with zero UK emissions).

The monthly modelled concentrations for the simulation with zero UK emissions are also shown in Fig. 8 (green line). The modelled monthly $\mathrm{NO}_{3}^{-}$concentrations (blue line) were enhanced by $2.6 \mu \mathrm{g} \mathrm{m}^{-3}$ by UK emissions in February, but by $5.0 \mu \mathrm{g} \mathrm{m}^{-3}$ in March and by $2.6 \mu \mathrm{g} \mathrm{m}^{-3}$ in April as compared with the model simulation with no UK emissions (green line). The daily mean model $\mathrm{NO}_{3}^{-}$concentrations highlight substantial temporal variability within this February-April period. The daily average surface concentrations (orange line of Fig. 8) show three separate episodes; the first approximately matches the period 12-28 February (F), the second 10-27 March (M) and the third 1-30 April (A).

The characteristic differences between these three periods are illustrated in Fig. 9. Here the 12:00 wind vector is superimposed to the mean modelled surface concentration of PM $\mathrm{NO}_{3}^{-}$for selected days during the three component episodes. It is seen that 12-15 February (episode F) and 17-20 March (episode $\mathrm{M}$ ) were associated with stagnant air masses allowing $\mathrm{NO}_{3}^{-} \mathrm{PM}$ concentrations to build up, while the period 11-14 April (episode A) was associated with a highlight polluted air mass arriving from the east.

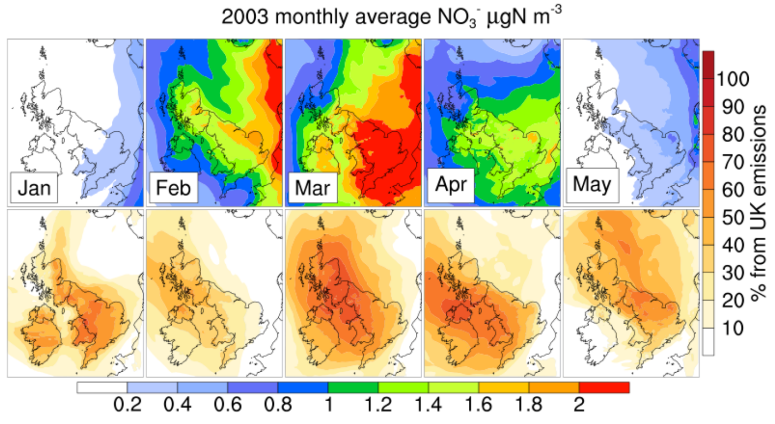

a)

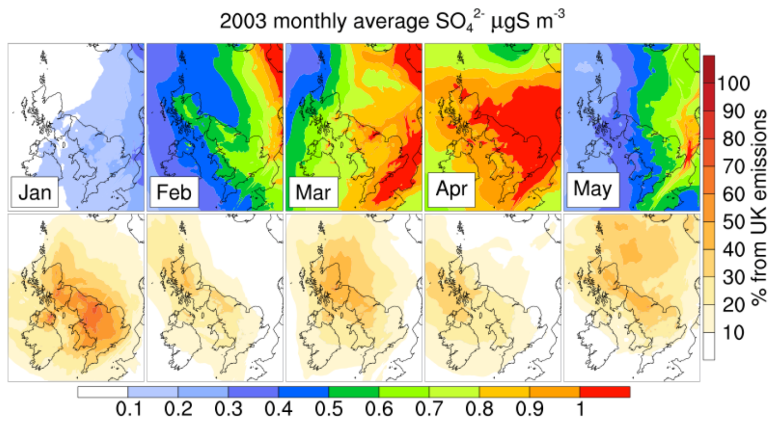

b)

Figure 7. Modelled monthly average surface concentrations and UK contributions for (a) $\mathrm{NO}_{3}^{-}$and (b) $\mathrm{SO}_{4}^{2-}$ from January to May 2003. In each case the upper panel shows the mean concentrations ( $\mu \mathrm{g} \mathrm{N} \mathrm{m}^{-3}$ or $\mu \mathrm{g} \mathrm{S} \mathrm{m}{ }^{-3}$ ), while the lower panel shows the percentage contribution from UK emissions (calculated as $[100 \times($ Base - no UK emi)/Base] between the base simulation and the simulation with zero UK emissions).

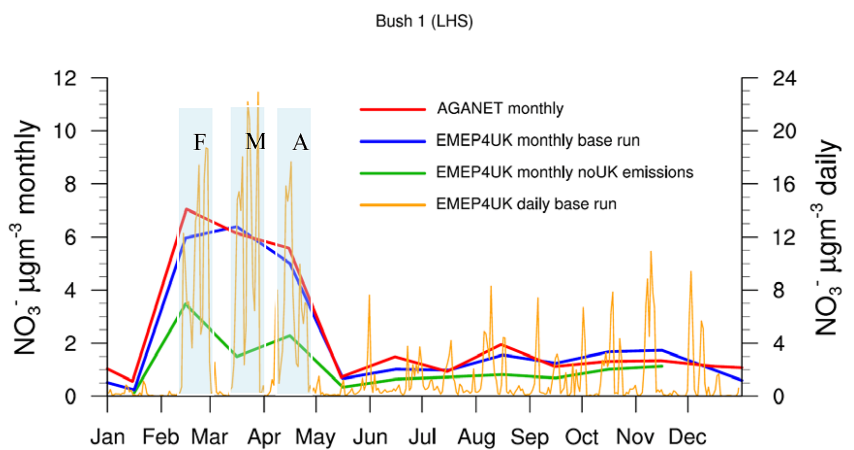

Figure 8. Modelled and observed monthly mean (left axis) and daily mean (right axis) surface concentrations of $\mathrm{NO}_{3}^{-}$at the Bush site (Scotland) for the year 2003. The red line shows the measured monthly values from the AGANet network, the blue line shows the modelled monthly means for the base run, the green line shows the modelled monthly means for the experiment with no UK emissions, and the orange line shows the modelled daily means for the base run (all model values are averages of hourly data). The blue shadows highlight the three episodes labelled F, M and A. 


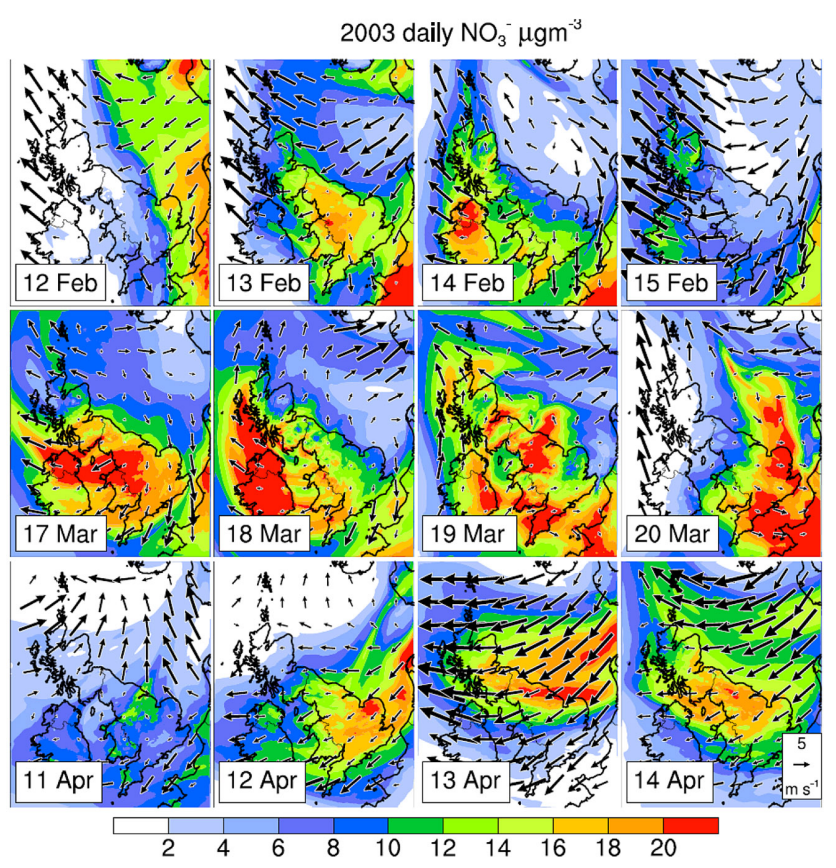

Figure 9. Modelled daily mean surface concentration of $\mathrm{NO}_{3}^{-}$and the 12:00 wind vector for 12-15 February (episode F), 17-20 March (episode M) and 11-14 April (episode A).

The UK February episode was associated with an easterly light wind advecting $\mathrm{PM} \mathrm{NO}_{3}^{-}$produced in the area of the north of France, Holland, north of Germany, and Denmark, where the centre of the high pressure was located (Fig. 9). During the March episode, the centre of the high pressure was over the UK with an associated light wind, clear sky, and cooler conditions leading to the accumulation of $\mathrm{NO}_{3}^{-}$ from UK emissions with little import of $\mathrm{NO}_{3}^{-}$or its precursors from outside the UK. The April episode was a mixture of conditions described for February and March.

The model sensitivity analyses of the proportions of UK nitrate and sulfate derived from UK emissions of anthropogenic precursors was extended over the whole period 2001-2010, and the results for the locations of the four study sites, Strathvaich Dam, Bush, Rothamsted and Yarner Wood (highlighted in Fig. 1) are shown in Fig. 10. The 10 years analysed here shows that the monthly averaged UK emissions contributions to $\mathrm{SO}_{4}^{2-}$ and $\mathrm{NO}_{3}^{-}$at these sites range from 10 to $80 \%$. Yarner Wood and Strathvaich Dam are closer than the other selected sites to areas of shipping emissions, therefore on average the $\mathrm{SO}_{4}^{2-}$ concentration at this site is less influenced by UK emissions compared with the other two sites.

Based on the simulations it is possible to estimate the annual contribution of non-UK emissions to the different components of $\mathrm{PM}_{10}$ at the four study sites. This is summarised in Fig. 11 for the year 2003, also including the contribution of primary particulate matter (emitted PM). Pollution
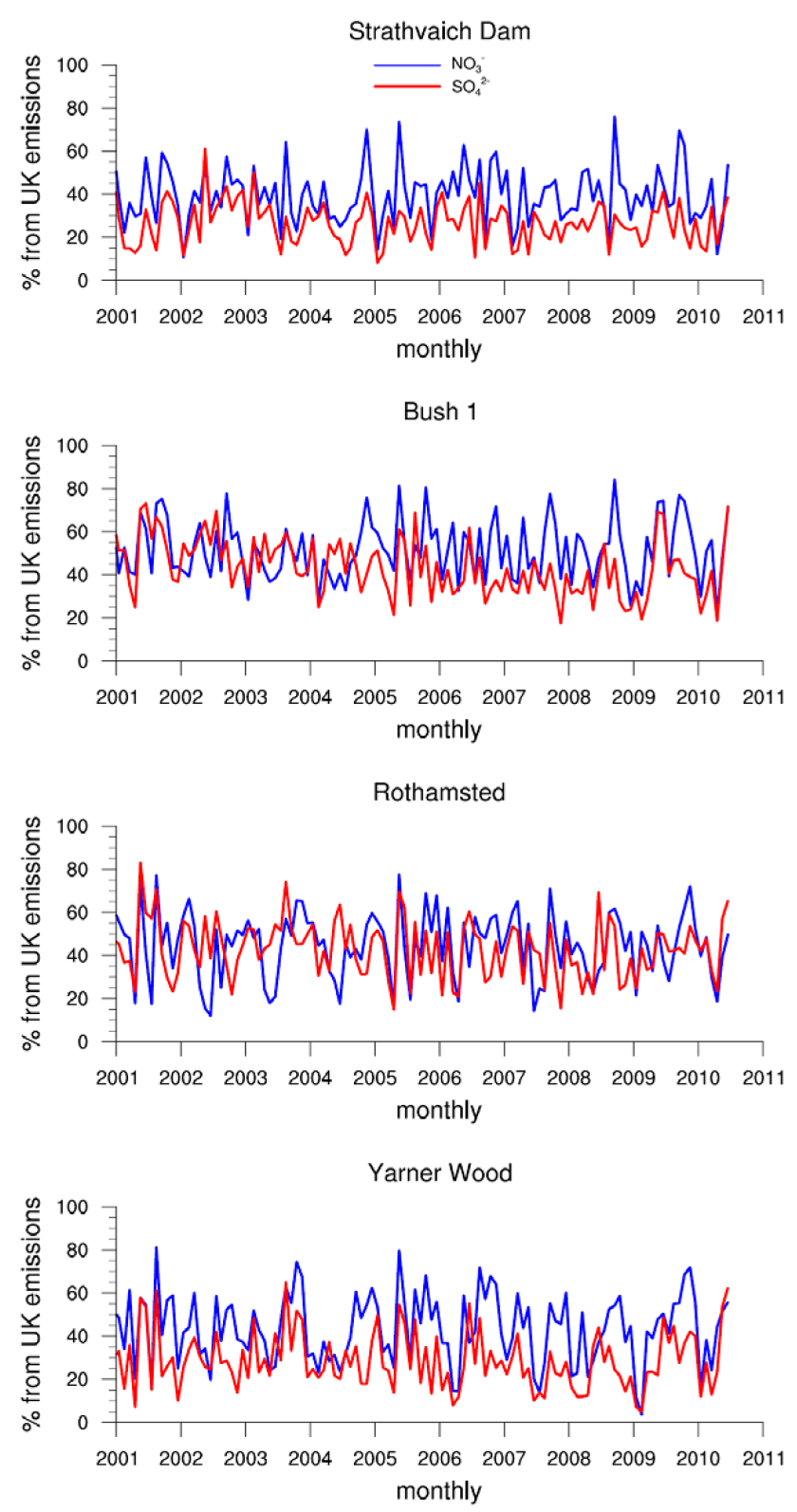

Figure 10. Modelled monthly average proportions of $\mathrm{NO}_{3}^{-}$(blue line) and $\mathrm{SO}_{4}^{2-}$ (red line) derived from UK precursor emissions, for four sites in the UK for the decade 2001-2010 (calculated as [100 $\times($ Base - no UK emi $) /$ Base $]$ between the base simulation and the simulation with zero UK emissions).

import for $\mathrm{PM}_{2.5}$ from non-UK sources ranges from an estimated $41 \%$ for Bush 1, up to $63 \%$ for Yarner Wood, highlighting the importance of transboundary pollution import on UK $\mathrm{PM}_{2.5}$ concentrations. The same model results for 2003 can be expressed in terms of the contribution of non-UK emissions to the current European Commission (EC, 2013) limit value for $\mathrm{PM}_{2.5}$ and to the World Health Organization (WHO, 2005) guideline value for $\mathrm{PM}_{2.5}$ at each of the four sites (Table 2). For these example sites, up to 18 and $45 \%$ 
Table 2. Model simulated contributions of Continental European $\mathrm{PM}_{2.5}$ import to the current European Commission limit value (EC, 2013) and to the World Health Organization guideline value (WHO, 2005) at each of the four sites for the EMEP4UK model simulations for the year 2003 .

\begin{tabular}{lllll}
\hline Continental European contribution & Strathvaich Dam & Bush 1 & Rothamsted & Yarner Wood \\
\hline EC limit value of $25 \mu \mathrm{g} \mathrm{m}^{-3}$ & $5 \%$ & $8 \%$ & $18 \%$ & $15 \%$ \\
WHO guideline of $10 \mu \mathrm{g} \mathrm{m}^{-3}$ & $14 \%$ & $20 \%$ & $45 \%$ & $38 \%$ \\
\hline
\end{tabular}

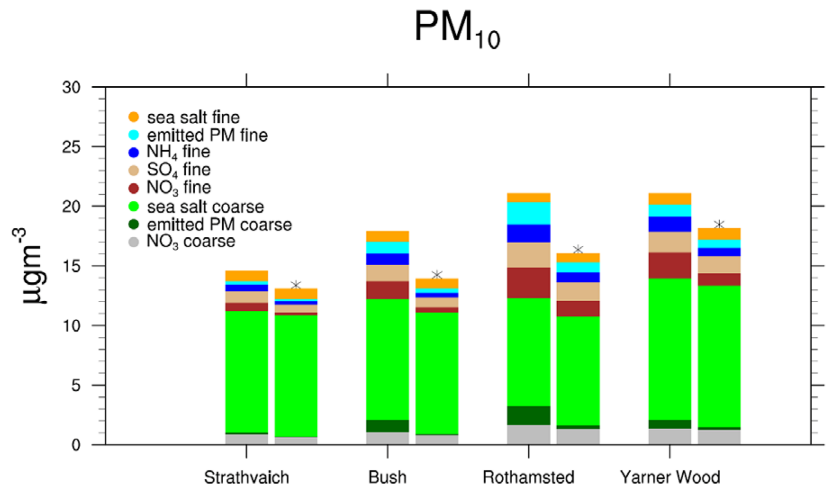

Figure 11. Mean composition of $\mathrm{PM}_{10}$ components as estimated by the EMEP4UK model for four sites across the UK, averaged for the whole of 2003. The model base run (including all national and international emissions) is compared with the results from a simulation excluding UK emissions (*). The difference in magnitudes between the pairs of adjacent bars indicates the PM derived from emissions within the UK. As well as the SIA components, the total modelled $\mathrm{PM}_{10}$ includes the contribution from emitted primary fine $\mathrm{PM}\left(\mathrm{PM}_{2.5}\right)$ and primary $\mathrm{PM}_{\text {coarse }}$ (i.e. $\left.\mathrm{PM}_{2.5-10}\right)$, and fine and coarse sea salt.

of the limit and guideline values, respectively, is provided by non-UK emissions.

\section{Discussion}

Inorganic particle components were simulated over the period 2001-2010. This is the first time that high spatial resolution $(5 \mathrm{~km})$ and temporal resolution $(1 \mathrm{~h})$ simulations of inorganic atmospheric species have been undertaken across the whole UK for a multi-year period, and the first time that the EMEP(4UK) simulations have been compared with the UK-wide AGANet monitoring network.

Two inorganic aerosol schemes were available for the EMEP and EMEP4UK model: the EQSAM (used in this work) and the MARS scheme (Simpson et al., 2012). As discussed in Sect. 2.1, both schemes use a bulk approach for particle formation. The EQSAM aerosol scheme was used here as it has demonstrated good performance in the TM5 atmospheric chemistry transport model (Karl et al., 2009; Huijnen et al., 2010). However, the bulk approach may lead to uncertainties in the simulated SIA, as shown in Hu et al. (2008), as the particle sizes are not explicitly resolved in the model. The current aerosols scheme and size partitioning in the EMEP model has been validated and compared with observations across Europe as shown in Fagerli and Aas (2008) and in Simpson et al. (2006). In addition, in a recent model intercomparison (Carslaw, 2011a, b) SIA and its gaseous precursors simulated by EMEP4UK showed good agreement with observations.

The smoother distribution of particle components (Figs. 5 and 7) as compared with their gaseous precursors (Figs. 4 and 6) reflects the longer timescales for forming these secondary pollutants, as compared with the emissions-driven patterns for the primary pollutant gases (AQEG, 2012). The lifetime for oxidation of $\mathrm{NO}_{\mathrm{x}}$ and $\mathrm{SO}_{2}$ to $\mathrm{HNO}_{3}$ and $\mathrm{H}_{2} \mathrm{SO}_{4}$ is up to a few days and comparable to transnational air-mass transport times. Hence the lifetime of formation plays an important role in determining the influence of non-UK emissions on SIA concentrations in the UK.

The highest modelled concentrations over this period are in 2003, particularly for $\mathrm{PM} \mathrm{NO}_{3}^{-}$and $\mathrm{NH}_{4}^{+}$, and to a lesser extent for $\mathrm{SO}_{4}^{2-}$, whilst lowest concentrations for each of these components are in 2008-2010.The notably high PM $\mathrm{NO}_{3}^{-}$concentrations in February to April 2003 were observed at AGANet stations across the UK and could be well reproduced by the model (Fig. 2, Table 1). Concentrations of $\mathrm{PM} \mathrm{SO}_{4}^{2-}$ were also elevated during this period, although by a smaller amount, and were also well captured by the model (Fig. 3, Table 1). The magnitude of this elevation in annual average $\mathrm{PM} \mathrm{NO}_{3}^{-}$concentration in 2003 is greater than the decline in annual average concentration across the whole decade to 2010 of $0.1-0.2 \mu \mathrm{g} \mathrm{N} \mathrm{m}^{-3}$ (Fig. 5). The $\mathrm{Au}-$ gust 2003 heatwave (Vieno et al., 2010) was not associated with high nitrate as the higher temperature limits the partitioning to the condensed phase. However, a secondary peak in sulfate is noted during summer 2003, which is directly attributed to the 2003 August heatwave, whereby elevated temperatures lead to faster $\mathrm{SO}_{2}$ oxidation to sulfate (Dawson et al., 2007; Jacob and Winner, 2009).

Although the magnitude of monthly/daily elevated $\mathrm{NO}_{3}^{-}$ is similar for the three months of February, March and April 2003, each month has a different characteristic. A distinctive meteorological feature for the three months was a persistent high pressure over the UK and Europe (unusual for this season) with an associated relatively cool temperature and little rainfall (not shown). The location and persistency 
of the high pressure strongly influenced the production and transport of $\mathrm{NO}_{3}^{-}$. Although emissions of $\mathrm{NO}_{3}^{-}$precursors are controlled, the model analysis shows the substantial influence of meteorology underpinning the high concentrations of $\mathrm{NO}_{3}^{-}$observed in the UK during the first part of 2003. Wang et al. (2014) examined the drivers of PM concentrations in the Shanghai region. Similar to our results for the UK they showed that meteorology determined whether the dominant contributor to PM concentrations was local emissions or regional transport. The authors suggest that particular attention should be given to emissions controls in the upwind adjacent provinces, as well as in local areas, for developing effective strategies to reduce $\mathrm{PM}_{2.5}$ pollution in Shanghai, again consistent with our conclusions. Zhang et al. (2014) also found that PM concentrations in central China have a clear link with long-range transport. A recent study in the USA by Mwaniki et al. (2014) showed nitrate to have a large variation in winter time, contributing substantially to elevated PM events.

The geographic origins of the PM episodes have been investigated in the model perturbation experiment. The monthly average surface concentrations for the zero UK emissions experiment show that surface concentrations of $\mathrm{SO}_{2}$ and $\mathrm{NO}_{2}$ are mainly driven by UK emissions (Fig. 6) and by similar proportions of UK emissions throughout the period of high surface concentrations of $\mathrm{NO}_{3}^{-}$. However, the proportions of the $\mathrm{NO}_{3}^{-}$that are derived from UK and nonUK emissions changes between months (Fig. 7). The model results show that for February 2003 trans-boundary emissions had a small influence on $\mathrm{NO}_{3}^{-}$, whereas for March and April the trans-boundary transport of $\mathrm{NO}_{3}^{-}$and/or its precursors was substantial. Abdalmogith et al. (2006) suggest that the annual average import of $\mathrm{NO}_{3}^{-}$aerosol to the UK from Europe (as an average of 2002 and 2003) is between 35 and $65 \%$ of the UK total $\mathrm{NO}_{3}^{-}$concentration. Our study has found that, for 2003 (Fig. 7), the import to the UK from Europe was in the range $20-60 \%$ of UK total $\mathrm{NO}_{3}^{-}$concentrations, with this proportion varying between the three episodes (labelled F, M and A in Fig. 8). Abdalmogith et al. (2006) concluded that the $2003 \mathrm{NO}_{3}^{-}$ spring event was not well represented by their model, and the low emissions resolution $(10 \mathrm{~km} \times 10 \mathrm{~km}$ grid $)$ was suggested as a possible cause. In the present study the elevated $\mathrm{NO}_{3}^{-}$concentrations are well represented by the EMEP4UK model at $5 \mathrm{~km} \times 5 \mathrm{~km}$ resolution. However, we find that simulation at $50 \mathrm{~km} \times 50 \mathrm{~km}$ horizontal spatial resolution of the EMEP4UK model outer domain also represented these features (results not included here), indicating that transport and dispersion were the main drivers of the pollution events. As shown in Fig. 10, over the full 10-year period there was a substantial variation (10 to $80 \%$ ) in the contribution of UK emissions to SIA concentrations in the UK.

The simulated changes in the gaseous precursors for 20012010 follow the reductions in UK emissions over that period especially for $\mathrm{NO}_{2}$ and $\mathrm{SO}_{2}$ (MacCarthy et al., 2012). The change of $\mathrm{SO}_{2}$ annual surface concentration especially after 2007 over the North Sea (Fig. 4b) is a direct response to the introduction of a sulfur emission control area (SECA) in the North Sea, including the English Channel, by the 2007 MARPOL convention on marine pollution (Dore et al., 2007). Under the convention the sulfur content of bunker fuel was restricted to $1.5 \%$ by mass in 2007 (and will be further reduced to $0.1 \%$ in SECAs by 2020). This has resulted in a substantial reduction of emissions of $\mathrm{SO}_{2}$ from the shipping sector.

The results in Figs. 4 and 5 illustrate the non-linear relationship between changes over time in $\mathrm{SO}_{2}$ and $\mathrm{NO}_{2}$ surface concentrations over the 2001-2010 decade and changes in the respective $\mathrm{PM} \mathrm{SO}_{4}^{2-}$ and $\mathrm{NO}_{3}^{-}$concentrations. The sensitivity of $\mathrm{PM} \mathrm{SO}_{4}^{2-}$ to changes in its precursors is, however, considerably greater than for $\mathrm{NO}_{3}^{-}$. The small decline in $\mathrm{NO}_{3}^{-}$and low sensitivity to UK $\mathrm{NO}_{\mathrm{x}}$ emission found in this work was supported by the results in Harrison et al. (2013). The formation of both $\mathrm{NO}_{3}^{-}$and $\mathrm{SO}_{4}^{2-}$ requires $\mathrm{NH}_{4}^{+}$as a counter-ion and there appear to be sufficient $\mathrm{NH}_{3}$ emissions not to be a limiting factor to $\mathrm{SO}_{4}^{2-}$ formation. Conversely, UK $\mathrm{NO}_{\mathrm{x}}$ emissions are still relatively high, especially in urban areas, so with an abundance of $\mathrm{NO}_{\mathrm{x}}$ available for formation of ammonium nitrate available $\mathrm{NH}_{3}$ eventually may be consumed. Consequently, in areas of high $\mathrm{NO}_{\mathrm{x}}$ emissions, $\mathrm{NO}_{3}^{-}$formation appears to be more sensitive to $\mathrm{NH}_{3}$ emissions than is the case for $\mathrm{SO}_{4}^{2-}$ formation. This is consistent with Redington et al. (2009) whose modelling showed that $\mathrm{SO}_{4}^{2-}$ formation in the UK was less sensitive to a $30 \% \mathrm{NH}_{3}$ emissions reduction than $\mathrm{NO}_{3}^{-}$formation.

The modelled annual average $\mathrm{NH}_{4}^{+}$shows a change between 2001 and 2010 over the UK which is intermediate between that of $\mathrm{NO}_{3}^{-}$and $\mathrm{SO}_{4}^{2-}$ (Fig. 5c). By 2010, $\mathrm{NH}_{4}^{+}$ concentrations decreased by $0.3-0.4 \mu \mathrm{g} \mathrm{N} \mathrm{m}^{-3}$ over most of England, but, as was the case for $\mathrm{NO}_{3}^{-}$concentrations, annual average $\mathrm{NH}_{4}^{+}$concentrations in 2003 were elevated by $0.2-0.3 \mu \mathrm{g} \mathrm{N} \mathrm{m}^{-3}$ compared with preceding and subsequent years. This confirms that the episodes of elevated $\mathrm{NO}_{3}^{-}$in 2003 were driven by ammonium nitrate specifically. The modelled decrease in $\mathrm{PM} \mathrm{NH}_{4}^{+}$concentrations as compared with minimal decrease (and some increase) in $\mathrm{NH}_{3}$ concentrations over the period 2001-2010 is consistent with the conclusions of Bleeker et al. (2009) and Horvath et al. (2009) for other parts of Europe that reducing $\mathrm{SO}_{2}$ emissions have contributed to maintaining or even increasing gaseous $\mathrm{NH}_{3}$ concentrations.

Current EU legislation has established a limit value of $25 \mu \mathrm{g} \mathrm{m}^{-3}$ for annual mean $\mathrm{PM}_{2.5}$ for the protection of human health; at the same time, the World Health Organization (WHO) publishes a guideline value of $10 \mu \mathrm{g} \mathrm{m}^{-3}$ annual mean $\mathrm{PM}_{2.5}$ for the protection of human health. As Fig. 11 illustrates, determining the contribution of transboundary and regional transport to local PM concentrations is vital to inform policy development, as local measures can only address 
the local contribution. For the four sites analysed for 2003, Fig. 11 shows the share of non-UK contribution to modelled $\mathrm{PM}_{2.5}$ concentrations ranging from $63 \%$ (Yarner Wood) to $41 \%$ (Bush 1). It is also clear that $\mathrm{PM}_{10}$ at these locations is dominated by sea salt. As these stations are representative of rural or background levels, it is likely that the relative longrange contribution to $\mathrm{PM}_{2.5}$ concentrations at urban hotspots is smaller, but still substantial.

Table 2 expresses the non-UK contribution to modelled annual mean $\mathrm{PM}_{2.5}$ relative to the EC limit value and $\mathrm{WHO}$ guideline value for $\mathrm{PM}_{2.5}$ (for the protection of human health). The non-UK contribution ranges from $5 \%$ at Strathvaich to $18 \%$ at Rothamsted for the limit value at $25 \mu \mathrm{g} \mathrm{m}{ }^{-3}$ (or 14 to $45 \%$ for the same sites with respect to the guideline value of $10 \mu \mathrm{g} \mathrm{m}^{-3}$ ). This indicates a clear gradient of nonUK contribution from greatest in the southeast and least in the north; this is likewise visible in Fig. 5.

The results presented here clearly demonstrate the need for international agreements to address the transboundary component of air pollution. If, for instance, an overall limit value of $10 \mu \mathrm{g} \mathrm{m}^{-3}$ were to be established following the WHO guideline, a substantial number of UK monitoring sites (Fig. 2) in particular in the south and southeast of the country may be close to or exceed annual mean limit values due to import of inorganic particle components from continental Europe under specific conditions.

In the view of these results, the rather moderate further reductions agreed by parties to the Convention on Long-range Transboundary Air Pollution in the revision of the Gothenburg Protocol (Reis et al., 2012) for the period between 2010 and 2020 would result in a substantial remaining contribution of transboundary aerosol transport to UK particulate matter concentrations for the next decade.

The results further illustrate how the inter-annual variability of surface concentrations of nitrate for the 2001-2010 decade as a response to changes in meteorological conditions is larger than the effect of changes in anthropogenic emissions. This suggests that for compliance assessment, an average over several years would provide a more robust basis than individual years, where a few short episodes can have a major influence.

\section{Conclusions}

For the first time the EMEP4UK model has been operated at high resolution for a multi-year period (2001-2010) and simulated secondary inorganic component concentrations compared with observations from the AGANet network. The drivers of three remarkably high secondary inorganic aerosol episodes across the UK have been investigated in detail, revealing contrasting causes for different periods. Whilst it has been documented that the bulk gas/particle partitioning approach used in these simulations (EQSAM formulation) may lead to uncertainties in simulated secondary inorganic aerosol, the EMEP4UK model was able to accurately represent both the long-term decadal (2001-2010) surface concentrations of particulate matter (PM) and specific episodes of elevated $\mathrm{PM} \mathrm{NO}_{3}^{-}$in 2003. The latter was identified as consisting of three separate episodes, each of less than 1 month duration, in February, March and April. The primary cause of the elevated nitrate levels across the UK was meteorological, related to a persistent high-pressure system, with the contribution of imported pollution differing markedly between these events.

The findings emphasise the importance of employing multiple year simulations in the assessment of emissions reduction scenarios on PM concentrations. The inter-annual variability of surface concentrations of nitrate for the 2001-2010 decade as a response to changes in meteorological conditions is larger than the effect of changes in anthropogenic emissions. For instance, up to $60 \%$ of $\mathrm{NO}_{3}^{-}$may be imported from outside the UK under specific conditions.

Our results highlight how inter-annual variability can profoundly affect the sensitivity to the attainment of limit values for ambient PM concentrations as a result of non-domestic contributions from transboundary air pollution transport.

Acknowledgements. This work is supported jointly by the UK Department for the Environment, Food and Rural Affairs (Defra) under the contract AQ0727, the NERC Centre for Ecology and Hydrology (CEH), the EMEP programme under the UNECE LRTAP Convention, the Norwegian Meteorological Institute and the European Union projects NitroEurope IP and ÉCLAIRE.

Edited by: A. Laskin

\section{References}

Aas, W., Tsyro, S., Bieber, E., Bergström, R., Ceburnis, D., Ellermann, T., Fagerli, H., Frölich, M., Gehrig, R., Makkonen, U., Nemitz, E., Otjes, R., Perez, N., Perrino, C., Prévôt, A. S. H., Putaud, J.-P., Simpson, D., Spindler, G., Vana, M., and Yttri, K. E.: Lessons learnt from the first EMEP intensive measurement periods, Atmos. Chem. Phys., 12, 8073-8094, doi:10.5194/acp12-8073-2012, 2012.

Abdalmogith, S. S., Harrison, R. M., and Zlatev, Z.: Intercomparison of secondary inorganic aerosol concentrations in the UK with predictions of the Unified Danish Eulerian Model, J. Atmos. Chem., 54, 43-66, doi:10.1007/s10874-006-9012-3, 2006.

Andersson-Skold, Y. and Simpson, D.: Comparison of the chemical schemes of the EMEP MSC-W and IVL photochemical trajectory models, Atmos. Environ., 33, 1111-1129, 1999.

AQEG: Fine Particulate Matter (PM2.5) in the United Kingdom. Air Quality Expert Group, UK Department for Environment, Food and Rural Affairs, London, PB13837, http://uk-air.defra.gov. uk/library/reports?report_id=727 (last access: 2 January 2014), 2012.

Berge, E. and Jakobsen, H. A.: A regional scale multi-layer model for the calculation of long-term transport and deposition of air pollution in Europe, Tellus B, 50, 205-223, 1998. 
Bleeker, A., Sutton, M. A., Acherman, B., Alebic-Juretic, A., Aneja, V. P., Ellermann, T., Erisman, J. W., Fowler, D., Fagerli, H., Gauger, T., Harlen, K. S., Hole, L. R., Horvath, L., Mitosinkova, M., Smith, R. I., Tang, Y. S., and van Pul, A.: Linking Ammonia Emission Trends to Measured Concentrations and Deposition of Reduced Nitrogen at Different Scales, in: Atmospheric Ammonia, Detecting emissions changes and environmental impacts, edited by: Sutton, M. A., Reis, S., and Baker, S. M. H., Springer, 123-180, ISBN 978-1-4020-9120-9, doi:10.1007/978-1-40209121-6_11, 2009.

Carslaw, D. C.: Report: Defra deposition model evaluation analysis - Phase 1, http://uk-air.defra.gov.uk/library/reports?report_ id=652 (last access: 8 January 2014), 2011 a.

Carslaw, D. C.: Report: Defra regional and transboundary model evaluation analysis - Phase 1, http://uk-air.defra.gov.uk/library/ reports?report_id=653 (last access: 8 January 2014), $2011 \mathrm{~b}$.

Conolly, C., Lawrence, H., Vincent, K., Donovan, B., Davies, M., Colbeck, C., Cape, J. N., Tang, Y. S., Bealey, W. J., Leaver, D., Poskitt, J., Beith, S., Thacker, S., Hockenhull, K., Woods, C., Simmons, I., Braban, C. F., van Dyke, N., Rowland, P., Fowler, D., and Sutton, M. A.: UK Eutrophying and Acidifying Atmospheric Pollutants (UKEAP) Annual Report 2010, 2011.

Dawson, J. P., Adams, P. J., and Pandis, S. N.: Sensitivity of $\mathrm{PM}_{2.5}$ to climate in the Eastern US: a modeling case study, Atmos. Chem. Phys., 7, 4295-4309, doi:10.5194/acp-7-4295-2007, 2007.

Dore, A. J., Vieno, M., Tang, Y. S., Dragosits, U., Dosio, A., Weston, K. J., and Sutton, M. A.: Modelling the atmospheric transport and deposition of sulphur and nitrogen over the United Kingdom and assessment of the influence of $\mathrm{SO}_{2}$ emissions from international shipping, Atmos. Environ., 41, 2355-2367, doi:10.1016/j.atmosenv.2006.11.013, 2007.

Dore, A. J., Theobald, M. R., Kryza, M., Vieno, M., Tang, S. Y., and Sutton, M. A.: Modelling the deposition of reduced nitrogen at different scales in the United Kingdom, Nato Sci. Peace Secur., 127-135, 2008.

EC: European Commission, Air Quality Standards, http://ec.europa. eu/environment/air/quality/standards.htm, last access: 15 October 2013.

ENTEC: Defra, UK ship emissions inventory, final report, http://uk-air.defra.gov.uk/reports/cat15/1012131459_21897_

Final_Report_291110.pdf, Crown copyright, 2010.

Fagerli, H. and Aas, W.: Trends of nitrogen in air and precipitation: Model results and observations at EMEP sites in Europe, 1980-2003, Environ. Pollut., 154, 448-461, doi:10.1016/j.envpol.2008.01.024, 2008.

Harrison, R. M., Stedman, J., and Derwent, D.: New directions: Why are $\mathrm{PM}_{10}$ concentrations in Europe not falling?, Atmos. Environ., 42, 603-606, doi:10.1016/j.atmosenv.2007.11.023, 2008.

Harrison, R. M., Jones, A. M., Beddows, D. C. S., and Derwent, R. G.: The effect of varying primary emissions on the concentrations of inorganic aerosols predicted by the enhanced UK Photochemical Trajectory Model, Atmos. Environ., 69, 211-218, doi:10.1016/j.atmosenv.2012.12.016, 2013.

Heal, M. R., Kumar, P., and Harrison, R. M.: Particles, air quality, policy and health, Chem. Soc. Rev., 41, 6606-6630, doi:10.1039/C2cs35076a, 2012.

Hellsten, S., Dragosits, U., Place, C. J., Vieno, M., Dore, A. J., Misselbrook, T. H., Tang, Y. S., and Sutton, M. A.: Modelling the spatial distribution of ammonia emissions in the UK, Environ. Pollut., 154, 370-379, doi:10.1016/j.envpol.2008.02.017, 2008.

Horvath, L., Fagerli, H., and Sutton, M. A.: Long-Term Record (1981-2005) of Ammonia and Ammonium Concentrations at K-Puszta Hungary and the Effect of Sulphur Dioxide Emission Change on Measured and Modelled Concentrations, in: Atmospheric Ammonia, Detecting emissions changes and environmental impacts, Springer, edited by: Sutton, M. A., Reis, S., and Baker, S. M. H., 181-185, ISBN 978-1-4020-9120-9, doi:10.1007/978-1-4020-9121-6_12, 2009.

Hu, X.-M., Zhang, Y., Jacobson, M. Z., and Chan, C. K.: Coupling and evaluating gas/particle mass transfer treatments for aerosol simulation and forecast, J. Geophys. Res.-Atmos., 113, D11208, doi:10.1029/2007jd009588, 2008.

Huijnen, V., Williams, J., van Weele, M., van Noije, T., Krol, M., Dentener, F., Segers, A., Houweling, S., Peters, W., de Laat, J., Boersma, F., Bergamaschi, P., van Velthoven, P., Le Sager, P., Eskes, H., Alkemade, F., Scheele, R., Nédélec, P., and Pätz, H.-W.: The global chemistry transport model TM5: description and evaluation of the tropospheric chemistry version 3.0, Geosci. Model Dev., 3, 445-473, doi:10.5194/gmd-3-445-2010, 2010.

IGCB: An economic analysis to inform the air quality strategy. Updated third report of the Interdepartmental Group on Costs and Benefits, Department for Environment, Food and Rural Affairs, PB12637, 2007.

Jacob, D. J. and Winner, D. A.: Effect of climate change on air quality, Atmos. Environ., 43, 51-63, doi:10.1016/j.atmosenv.2008.09.051, 2009.

Karl, M., Tsigaridis, K., Vignati, E., and Dentener, F.: Formation of secondary organic aerosol from isoprene oxidation over Europe, Atmos. Chem. Phys., 9, 7003-7030, doi:10.5194/acp-97003-2009, 2009.

MacCarthy, J., Thistlethwaite, G., Salisbury, E., Pang, Y., and Misselbrook, T.: Air Quality Pollutant Inventories for England, Scotland, Wales and Northern Ireland: 19902010, http://uk-air.defra.gov.uk/reports/cat07/1209130947_DA_ AQPI_2010_MainBody_v1.pdf (last access: 12 January 2013), 2012.

Metzger, S., Dentener, F., Krol, M., Jeuken, A., and Lelieveld, J.: Gas/aerosol partitioning - 2. Global modeling results, J. Geophys. Res.-Atmos., 107, ACH 17-1-ACH 17-23, doi:10.1029/2001jd001103, 2002a.

Metzger, S., Dentener, F., Pandis, S., and Lelieveld, J.: Gas/aerosol partitioning: 1. A computationally efficient model, J. Geophys. Res.-Atmos., 107, pages ACH 16-1-ACH 16-24, doi:10.1029/2001jd001102, 2002b.

Mwaniki, G. R., Rosenkrance, C., Wallace, H. W., Jobson, B. T., Erickson, M. H., Lamb, B. K., Hardy, R. J., Zalakeviciute, R., and VanReken, T. M.: Factors contributing to elevated concentrations of $\mathrm{PM}_{2.5}$ during wintertime near Boise, Idaho, Atmos. Pollut. Res., 5, 96-103, doi:10.5094/apr.2014.012, 2014.

Putaud, J. P., Van Dingenen, R., Alastuey, A., Bauer, H., Birmili, W., Cyrys, J., Flentje, H., Fuzzi, S., Gehrig, R., Hansson, H. C., Harrison, R. M., Herrmann, H., Hitzenberger, R., Huglin, C., Jones, A. M., Kasper-Giebl, A., Kiss, G., Kousa, A., Kuhlbusch, T. A. J., Loschau, G., Maenhaut, W., Molnar, A., Moreno, T., Pekkanen, J., Perrino, C., Pitz, M., Puxbaum, H., Querol, X., Rodriguez, S., Salma, I., Schwarz, J., Smolik, J., Schneider, J., Spindler, G., ten Brink, H., Tursic, J., Viana, M., Wiedensohler, A., and Raes, 
F.: A European aerosol phenomenology-3: Physical and chemical characteristics of particulate matter from 60 rural, urban, and kerbside sites across Europe, Atmos. Environ., 44, 1308-1320, doi:10.1016/j.atmosenv.2009.12.011, 2010.

Redington, A. L., Derwent, R. G., Witham, C. S., and Manning, A. J.: Sensitivity of modelled sulphate and nitrate aerosol to cloud, pH and ammonia emissions, Atmos. Environ., 43, 3227-3234, doi:10.1016/j.atmosenv.2009.03.041, 2009.

Reis, S., Grennfelt, P., Klimont, Z., Amann, M., ApSimon, H., Hettelingh, J. P., Holland, M., LeGall, A. C., Maas, R., Posch, M., Spranger, T., Sutton, M. A., and Williams, M.: From Acid Rain to Climate Change, Science, 338, 1153-1154, doi:10.1126/science.1226514, 2012.

RoTAP: Review of Transboundary Air Pollution: Acidification, Eutrophication,Ground Level Ozone and Heavy Metals in the UK. Contract Report to the Department for Environment, Centre for Ecology \& Hydrology, http://www.rotap.ceh.ac.uk/about (last access: 12 January 2013), 2012.

Simpson, D., Guenther, A., Hewitt, C. N., and Steinbrecher, R.: Biogenic Emissions in Europe. 1. Estimates and Uncertainties, J. Geophys. Res.-Atmos., 100, 22875-22890, 1995.

Simpson, D., Fagerli, H., Hellsten, S., Knulst, J. C., and Westling, O.: Comparison of modelled and monitored deposition fluxes of sulphur and nitrogen to ICP-forest sites in Europe, Biogeosciences, 3, 337-355, doi:10.5194/bg-3-337-2006, 2006.

Simpson, D., Benedictow, A., Berge, H., Bergström, R., Emberson, L. D., Fagerli, H., Flechard, C. R., Hayman, G. D., Gauss, M., Jonson, J. E., Jenkin, M. E., Nyíri, A., Richter, C., Semeena, V. S., Tsyro, S., Tuovinen, J.-P., Valdebenito, Á., and Wind, P.: The EMEP MSC-W chemical transport model - technical description, Atmos. Chem. Phys., 12, 7825-7865, doi:10.5194/acp-127825-2012, 2012.

Sutton, M. A., Miners, B., Tang, Y. S., Milford, C., Wyers, G. P., Duyzer, J. H., and Fowler, D.: Comparison of low cost measurement techniques for long-term monitoring of atmospheric ammonia, J. Environ. Monit., 3, 446-453, 2001.

Tang, Y. S., Simmons, I., van Dijk, N., Di Marco, C., Nemitz, E., Dammgen, U., Gilke, K., Djuricic, V., Vidic, S., Gliha, Z., Borovecki, D., Mitosinkova, M., Hanssen, J. E., Uggerud, T. H., Sanz, M. J., Sanz, P., Chorda, J. V., Flechard, C. R., Fauvel, Y., Ferm, M., Perrino, C., and Sutton, M. A.: European scale application of atmospheric reactive nitrogen measurements in a low-cost approach to infer dry deposition fluxes, Agr. Ecosyst. Environ., 133, 183-195, doi:10.1016/j.agee.2009.04.027, 2009.
Tang, Y. S., Poskitt, J., Cape, J. N., Nemitz, E., Bealey, W. J., Leaver, D., Beith, S., Thacker, S., Simmons, I., Letho, K., Wood, C., Pereira, G., Sutton, M. A., Davies, M., Conolly, C., Donovan, B., and Braban, C. F.: UK Eutrophying and Acidifying Atmospheric Pollutant project's Acid Gas and Aerosol Network (Data funded by Defra and the Devolved Administrations and published under the Open Government Licence v1.0, AGANet, http://uk-air. defra.gov.uk/networks/network-info?view=ukeap), last access: 10 January 2013.

Vieno, M., Dore, A. J., Wind, P., Di Marco, C., Nemitz, E., Phillips, G., Tarrason, L., and Sutton, M. A.: Application of the EMEP Unified Model to the UK with a Horizontal Resolution of $5 \times 5 \mathrm{~km}^{2}$, in: Atmospheric Ammonia, Detecting emissions changes and environmental impacts, edited by: Sutton, M. A., Reis, S., and Baker, S. M. H., Springer, 367-372, ISBN 978-14020-9120-9, 2009.

Vieno, M., Dore, A. J., Stevenson, D. S., Doherty, R., Heal, M. R., Reis, S., Hallsworth, S., Tarrason, L., Wind, P., Fowler, D., Simpson, D., and Sutton, M. A.: Modelling surface ozone during the 2003 heat-wave in the UK, Atmos. Chem. Phys., 10, 7963-7978, doi:10.5194/acp-10-7963-2010, 2010.

Wang, Y. J., Li, L., Chen, C. H., Huang, C., Huang, H. Y., Feng, J. L., Wang, S. X., Wang, H. L., Zhang, G., Zhou, M., Cheng, P., Wu, M. H., Sheng, G. Y., Fu, J. M., Hu, Y., Russell, A. G., and Wumaer, A.: Source apportionment of fine particulate matter during autumn haze episodes in Shanghai, China, J. Geophys. Res.Atmos., 119, 1903-1914, doi:10.1002/2013jd019630, 2014.

WHO: World Health Organization, Air quality guidelines. Global update 2005. Particulate matter, ozone, nitrogen dioxide and sulfur dioxide, http://www.euro.who.int/_data/assets/pdf_file/ 0005/78638/E90038.pdf (last access: 3 January 2013), 2005.

Yin, J. X. and Harrison, R. M.: Pragmatic mass closure study for $\mathrm{PM}_{1.0}, \mathrm{PM}_{2.5}$ and $\mathrm{PM}_{10}$ at roadside, urban background and rural sites, Atmos. Environ., 42, 980-988, doi:10.1016/j.atmosenv.2007.10.005, 2008.

Zhang, F., Cheng, H. R., Wang, Z. W., Lv, X. P., Zhu, Z. M., Zhang, G., and Wang, X. M.: Fine particles $\left(\mathrm{PM}_{2.5}\right)$ at a CAWNET background site in Central China: Chemical compositions, seasonal variations and regional pollution events, Atmos. Environ., 86, 193-202, doi:10.1016/j.atmosenv.2013.12.008, 2014. 